\title{
FAITH-BASED ORGANISATIONS IN THE CONTEXT OF SOCIAL WELFARE AND DEVELOPMENT IN SOUTH AFRICA: TOWARDS A CONCEPTUALISATION ${ }^{1}$
}

\section{Willie van der Merwe, Ignatius Swart, Jurgens Hendriks}

\section{INTRODUCTION}

In South Africa the state strongly expects the religious sector - or more specifically the collectivity of faith-based organisations constituting this sector - to make a meaningful contribution towards the country's struggle against poverty and HIV and AIDS (Koegelenberg, 2001, 2007; Swart, 2008). The debate on the role and contribution of faith-based organisations (hereafter FBOs) in social welfare and social development is not unique to South Africa, however, and has been conducted in other parts of the world for the last decade or more (Cameron, 2004; Cnaan, Farnell, 2001; Jeavons, 2004; Netting, 1984; Netting, Thibault \& Ellor, 1990:17; Smith, 2002; Wineburg \& Boddie, 1999; Yeung, 2003). Although the debate has been going on for quite some time, generally speaking the terms "religious sector" and "faith-based organisations" are still used in a vague and unfocused sense in the literature and no widely accepted definition can be found. This causes confusion about exactly what kinds of organisation are being referred to (Netting, 2004:136; Sider \& Unruh, 2004:109).

The lack of a clearer definition of who or what FBOs are also presents a challenge for the development of social welfare and development policy in South Africa. This article is accordingly based on the premise that the point has been reached in the designing and operationalisation of such policies where it has become critically important to obtain greater clarity on the identity, position and function of FBOs. Although the White Paper for Social Welfare recognises the distinctive nature of FBOs by classifying them as a specific category of organisation (Ministry for Welfare and Population Development, 1997:13), a more precise description of who the FBOs are exactly becomes necessary in order to establish the framework and contents of the partnership between the state and the religious sector as set out in the expectations of the state.

Indeed, the question about the nature and identity of FBOs should be considered as central to the ongoing debate about the place and role of the religious sector in the sphere of social welfare and social development in South Africa. The expectations that the state has of the religious sector can easily lead to a situation where FBOs are drawn into forming part of the agenda of the state, with the possible result that this could minimise the peculiar character, identity and social contribution of FBOs. Sider and Unruh, writing in the context of the North American debate, warn about this danger:

Another danger is that public policy may exploit religion's social contributions to mask the deconstruction of public responsibility for society's most vulnerable. While faith communities may promote the values and civic habits that sustain political institutions, they bear this role in tension with their prophetic calling to hold these institutions accountable to transcendent standards of justice... (Unruh \& Sider, 2005:259)

\footnotetext{
${ }^{1}$ This material is based upon work supported by the National Research Foundation under grant number 2054070. Any opinion, findings, and conclusions or recommendations expressed in this material are those of the authors and therefore the NRF does not accept any liability in regard thereto.
} 
While the issue of a partnership between the state and the religious sector in the sphere of social welfare and development delivery constitutes an important point of reference in this article, it is not the primary focus. Instead, the article seeks to contribute in an exploratory way to the conceptualisation of FBOs in the post-apartheid South African social welfare and development context. A literature study was undertaken to establish trends in the international debate on the conceptualisation of FBOs. The main aim was to examine the progress that has been made. From the existing corpus of literature it became clear that the research undertaken by Ronald Sider and Heidi Rolland Unruh in the context of the United States in recent years has made a particularly important contribution. The typology that they developed therefore forms an important part of the argument of this article.

\section{THE NEED FOR A CLEARER DEFINITION}

There are a number of reasons why a clearer definition of FBOs is necessary. Sider and Unruh argue that the lack of clarity creates problems in three areas. Firstly, the lack of clear categories hampers comparative research on the effectiveness of organisations. By not carefully distinguishing the religious characteristics of a programme, the role of faith can either be understated or overstated. Secondly, failure to recognise a variety of FBOs and to define them clearly can lead to incongruous funding decisions. Prohibitions against funding of religious entities may lead to the disqualification of organisations or programmes because their relationship with a faith group is unclear and not well defined. Thirdly, there is a need to correct the undifferentiated language that often appears in public policy debates. Sider and Unruh conclude in this regard that "a one-size-fits-all language yields one-size-fits-all policies". According to them, what is actually needed is a whole wardrobe of options (Sider \& Unruh, 2004:110).

The need for more precise definitions as advocated by Sider and Unruh is also present in the current South African debate on the role of FBOs in social development. In their study of the non-profit sector in South Africa, Swilling and Russell came to the conclusion that more research needs to be done on the contribution of this sector, with one of the advantages being that "the non-profit sector will be able to enhance its identity and knowledge of its role in the development and democratic process" (Swilling \& Russell, 2002:95). If this is valid for the broader non-governmental sector, it should certainly also be regarded as true for the religious sector.

The point has already been made that the South African state has considerable expectations of the religious sector and that reference to FBOs can be found in various policy documents (Department of Social Development, 2006; Ministry for Welfare and Population Development, 1997; Republic of South Africa, 2007). However, adequate policies that will enable FBOs to become involved in the social welfare and development sector in a way that preserves their unique identity are still lacking. Therefore an integral part of social welfare policies should be to define FBOs more clearly in terms of their characteristics.

To illustrate the need for a clearer definition of the concept "faith-based organisation" in the South African context, the following development should be pointed out briefly. In the past decade, especially under the leadership of the Ecumenical Foundation of Southern Africa (EFSA) and the National Religious Association for Social Development (NRASD), a movement came into being to convince the state to acknowledge faith groups and FBOs as a unique and separate sector in civil society and to enter into a specific partnership with this sector that would entail funding for social development projects. These deliberations led to a 
"Memorandum of Understanding" between the state and religious leaders, which was signed in 2005. The partnership that is described in this memorandum has two dimensions. Firstly, it provides for the possibility that the state can make funds available to the religious sector for certain projects and programmes for social development; secondly, it makes provision for joint projects between the state and the religious sector (Koegelenberg, 2007).

However, in the process of operationalising the memorandum, various shortcomings soon became apparent. One such shortcoming is that the memorandum gives no clear indication of what is meant by the religious sector. This causes uncertainty amongst prospective participants as to whether they themselves will be regarded as part of the religious sector and whether their applications to be part of the partnership between the state and the religious sector will be accepted. Another shortcoming is that the memorandum does not set out a clear policy on how applications from the religious sector will be treated, that is, whether existing policy and legislation will apply or whether a new policy will be developed for the sector.

The above example clearly suggests that the development of policy for social welfare and development in South Africa has reached a stage where it has become critically important to define the religious sector and the FBOs within this sector more precisely. The absence of such definition leads to confusion that manifests itself on at least three levels. On the first level it has to do with the identities of FBOs. Who are the FBOs? Are they faith groups in a general sense, or do they refer to organised faith communities like churches, synagogues, mosques and temples? Or do they refer to organised social welfare organisations operating on a specific basis of faith? Another level of confusion has to do with the status that could possibly be assigned to the religious sector. The question then arises as to why FBOs are singled out. Is it not a fact that FBOs form part of civil society and the non-governmental sector? A third level of the debate concerns the contribution expected from the religious sector. Can FBOs make a unique contribution and what will it be? Are the same contributions not made by other organisations in society?

Sider and Unruh (2004:110) suggest that a typology that organises FBOs into meaningful categories based on their religious nature could contribute significantly to dialogue and research on the role of FBOs in addressing social problems.

\section{THE QUEST FOR THE UNIQUE CHARACTERISTICS OF FBOS}

The challenge in the conceptualisation of FBOs seems to be arriving at an appropriate description of the unique characteristics of this category of organisation in contrast to other organisations in the social welfare sector. However, a study of the existing literature on the subject clearly shows that this matter is not as straightforward as it appears to be. Whilst the obvious defining characteristic of FBOs may be the factor of faith or adherence to a faith community, the concept of "faith" or "religion" is in itself problematic. This aspect is, for instance, highlighted by Cnaan and his fellow writers when they warn that when the term "religious" is attached to any organisation that is not fully geared to carry out faith commands and practices, the notion of "religious" or "faith-based" as a descriptive term "becomes elusive" (Cnaan et al., 1999:25).

However, it remains a fact that FBOs want to distinguish themselves from other organisations and claim that they are unique. In this regard Koegelenberg observes that "(a)lthough there are many similarities on programme level between community-based NGOs and religious programmes ... religious communities have a different self-understanding and want to be 
recognised as religious communities" (Koegelenberg, 2001:98). The problem, it seems, is the lack of a common factor to describe this "self-understanding", as Koegelenberg calls it.

In the quest for a definition of an FBO it soon becomes clear that this is a multidimensional issue and that some of the dimensions are not as clear as they might seem at first. For instance, is the fact that an organisation developed historically from the actions of a faith group sufficient to define that organisation as a faith-based organisation? Or can we define as "religious" an organisation just because it operates from a religious organisation's property? (Cnaan et al., 1999:25).

Yet another dimension of the prism that can sometimes be very obscure is the so-called uniqueness of FBOs. Cnaan et al. (1999:26) conclude in this regard that in practice a wide variation can be found in the way that religious practices and expressions are incorporated in various social services. And as Unruh and Sider also correctly state, "faith-based ministries are not all based on the same faith, or related to faith in the same way. What makes a social ministry 'faith-full' in one instance may not apply in the next" (Unruh \& Sider, 2005:241).

Garland (1997:97) approaches the uniqueness question from another angle when she raises the question of how a social worker in a church set-up should define his or her responsibilities. Should there be a difference regarding the nature and aims of the work? She goes on to define church social work as social work that takes place under the protection of a church organisation, which can be a congregation, denominational agency or ecumenical or parachurch organisation. In this definition she defines the uniqueness of church social work in terms of the church context. Lindeque, a South African author, goes the same route when he defines church social work in the denominational context of the Dutch Reformed Church "as professional social work services rendered by this church's registered welfare organisation" (Lindeque, 1982:13).

It remains a question, however, whether the denominational or church context within which a social service programme is rendered provides sufficient grounds to define it as faith-based. Nevertheless, programme contents and practice models can be typical characteristics according to which a typology could be developed. This point is made by Unruh (2004:318), when she refers to many authors who compiled typologies using religious programme content as the one common factor. According to her, this is the one factor that can help to define FBOs and indicate how they express their religious identity.

Sider and Unruh give a useful overview of the various efforts of authors over the past few years to develop classification systems that can be used to classify FBOs. It becomes clear from this overview that some authors take the religious content of programmes and practices as a criterion. Others again look at the particular organisational model, namely the extent to which the organisation functions independently or under the control of a faith group. In conclusion, these researchers observe that there are certain central themes that all these models share. One theme relates to the issue of religious integration, or more precisely, the extent to which the religious phenomenon is incorporated into the activities of organisations. Another theme relates to the designing of a measurement for religious integration that would apply throughout different faith traditions. And a third theme relates to the fact that most authors acknowledge that there is no simple answer as to what exactly an FBO is. The faith nature of organisations is multidimensional and therefore these two authors suggest a typology of FBOs (Sider \& Unruh, 2004:10-116). 


\section{THE SIDER AND UNRUH TYPOLOGY OF RELIGIOUS CHARACTERISTICS}

In the light of the difficulty of identifying the unique characteristics of FBOs, it is suggested that the "Typology of Religious Characteristics" developed by Sider and Unruh (2004) merits further discussion for the way in which it combines a variety of characteristics to define the identity of a FBO in the social welfare and development sector. This typology was developed by these two authors in a project on "Congregations, Community Outreach and Leadership Development". The research project more specifically examined the community outreach programmes of congregations and included case studies of fifteen Protestant congregations in the greater Philadelphia area (USA) as well as interviews at a further twenty-one churches that were identified as churches actively involved in community outreach. On the basis of the research results a classification model was compiled that was presented to the "Working Group on Human Needs and Faith-Based and Community Initiatives" in the USA. According to the model, FBOs could be divided into five categories. Eight different organisational characteristics were furthermore identified and four typical characteristics of the different programmes were distinguished. Together these three aspects form the matrix that can be used to typify FBOs (Sider \& Unruh, 2004:117).

\section{The five categories of organisations}

In the typology FBOs are classified into the following five categories:

\section{Faith-permeated organisations}

These are organisations in which the connection with religious faith is clearly evident on all levels, for example, in the mission statement, the staff component and the management structures. In these types of organisations it is believed that the faith dimension is essential for the effectiveness of the programme and participation in religious exercises is often a prerequisite (Sider \& Unruh, 2004:119).

\section{Faith-centred organisations}

The organisations in this category were originally founded for a religious purpose and remain strongly connected to the faith community from which they originated. In these organisations the governing body and staff are required to be actively involved in the faith commitments of the organisation. Although this group of organisations has religious elements in its programmes, they are designed in such a way that participants can opt out and still expect the benefits of the programme's services (Sider \& Unruh, 2004:120).

\section{Faith-affiliated organisations}

These organisations retain some of the influence of their religious founders in their mission and ethos, but they do not expect of staff or members of the governing body to affirm religious beliefs or practices. Religious activities do not explicitly form part of the programmes, although they may affirm faith in a general way. The programmes may have the intention to convey a religious message through non-verbal acts of compassion and care (Sider \& Unruh, 2004:120).

\section{Faith-background organisations}

This group of organisations appears and acts like secular organisations, but they have a historic link with a faith tradition. It can be that for some members of staff their faith can motivate them to be part of these organisations, but faith is not a criterion for selection. The programmes of these organisations contain no specifically religious elements, except that the programmes can be housed in a religious setting (Sider \& Unruh, 2004:120). 


\section{Faith-secular partnerships}

This is a special type of organisation that comes into being when a secular organisation goes into partnership with one or more congregations or other explicitly religious organisations. This type of organisation is usually managed in a secular fashion, but it expects support from the churches and congregations in the form of volunteers and goods that the organisation needs. The leadership and staff need not share the faith of the church and congregation, and it is not a requirement for the programmes to have any religious contents (Sider \& Unruh, 2004:120).

\section{The organisational characteristics}

The typology also classifies organisations in terms of the following eight organisational elements:

\section{Mission and vision statement}

The first characteristic concerns the extent to which the organisation uses religious language or the language of a specific faith group to define the identity and aims of the organisation. This is an important aspect in the classification of organisations as FBOs, because the mission statement can either attract or filter out prospective members of staff, consumers and donors (Sider \& Unruh, 2004:121).

\section{Founding history}

This characteristic examines the connection between the organisation and a specific faith group in the past and in the present situation (Sider \& Unruh, 2004:121).

\section{Affiliation}

Sider and Unruh defined affiliation as a close relationship with another entity or agency that provides legal status, administrative structure and management of key resources to the organisation. This relationship can be officially arranged by a constitution or it may be more informal. The question is then whether that entity is religious or not. It is, however, a reality that not all FBOs are affiliated with another organisation or faith group, and hence this characteristic is not present in all FBOs (Sider \& Unruh, 2004:121).

\section{Control structures}

This characteristic has to do with the role that membership of a specific faith community plays in the selection of people for the control structures of a particular FBO or group of FBOs (Sider \& Unruh, 2004:121).

\section{Senior management}

As with the previous feature, this characteristic shows whether it is expected of people in senior management to belong to a specific faith group, to be a member of a specific denomination, or to maintain a specific religious lifestyle (Sider \& Unruh, 2004:122).

\section{Other staff members}

This characteristic reveals in what way faith plays a role in the selection and appointment of staff. This issue, however, is a hotly contested legal one. Court rulings in the USA, for example, distinguished between staff positions that are an integral part of the religious mission of the organisation and positions that fulfil primarily secular functions in the organisation (Sider \& Unruh, 2004:122).

\section{Support (financially and otherwise)}

This characteristic indicates how organisations raise financial and non-financial support, such as volunteer time and donations in kind. The question is whether FBOs target appeals for 
support only to a specific faith group or denomination, and whether FBOs exclude certain sources based on religious convictions (Sider \& Unruh, 2004:123).

\section{Religious practices of staff}

This characteristic has to do with the participation of the staff, volunteers and board members in organised religious practices (Sider \& Unruh, 2004:122).

\section{The four programme characteristics}

In the next instance the typology examines four programme characteristics of the organisations to establish their religious content:

\section{Religious environment}

This characteristic refers to the environment or space in which a programme is executed, for example, whether there are explicit symbols or references to a specific faith group (Sider \& Unruh, 2004:123).

\section{Programme content}

This characteristic shows whether specific religious activities form part of the programme, for example, devotion, singing, readings from holy books of a specific faith group, and whether invitations to take part in the religious activities of a specific faith group are extended (Sider $\&$ Unruh, 2004:123).

\section{Integration of religious components}

This characteristic reveals how beneficiaries of the service are likely to encounter religion in the context of the programme. In this regard the authors refer to previous research in which five general strategies for the integration of religion were developed: implicit, invitational, relational, integrated-optional and integrated-mandatory. These strategies are organised around three questions that have a bearing on the religious content of programmes. Are the religious dimensions of the programmes explicit? Is explicit religious content part of the programmes? Are explicit religious elements compulsory for participants of the programme, or can they be excused from participation? (Sider \& Unruh, 2004:123-124).

\section{Expected connection between religious content and desired outcome}

This characteristic looks at the expected connection between the spiritual technologies (religious activities) and the social service or programme. The methodology of faith-permeated and faith-centred programmes, for example, is shaped by the belief that religious outcomes, such as conversion, are essential to the desired social service outcome (Sider \& Unruh, 2004:124).

In the final analysis, Sider and Unruh acknowledge that their typology has its limitations and that the actual reality is more complex and therefore difficult to categorise (Sider \& Unruh, 2004:119). However, their classifications remain valuable, despite such possible deficiencies, and form an important basis on which further research can build. This is particularly true in the South African context, where there is no research that focuses on the conceptualisation of FBOs. 


\section{THE RELEVANCE OF SIDER AND UNRUH'S TYPOLOGY FOR THE SOUTH AFRICAN CONTEXT}

\section{Historical perspective}

In order to properly appreciate the relevance of Sider and Unruh's typology in the South African context, it is necessary first to describe briefly the place and role of churches and other civic organisations in the historical development of the country's social welfare sector.

In descriptions of the development of the social welfare sector and social work as a profession in England and the United States, the pioneering contribution of the Christian church and its leaders is widely acknowledged (Midgley \& Sanzenburg, 1989; Mupedziswa, 1996; Netting et al., 1990). This situation is no different in the case of South Africa, where the church sector likewise played a leading role in the development of the social welfare sector. Various authors have referred to the fact that the involvement of the church goes as far back as the arrival of the Dutch colonists in the middle of the seventeenth century. The Dutch East India Company (Vereenigde Oost-Indische Compagnie or VOC), which sent the colonists, had strong ties with the Reformed Church in the Netherlands. As a result of this relationship the colonists immediately started with a diaconal ministry similar to that of the church in their mother country (Botha, 1957:65; De Klerk, 1990:74; Patel, 2005:66). According to Nieuwoudt (1990:74-102), this ministry was initially characterised by alimentation or emergency relief, but there were also examples of "embryonic organised institutional care".

The history of many schools and institutions in South Africa tells the story of how the church responded to national disasters such as wars, epidemics, economic crises and other social needs. At the beginning of the previous century women's organisations also emerged. Up to the beginning of the $20^{\text {th }}$ century social welfare programmes were primarily rendered by religious groups and volunteer women's organisations. A separate State Department of Social Welfare was established only in 1937. It is important to note that before the establishment of the Department of Social Welfare there were very few pieces of legislation and policies regarding social welfare, and that the involvement of the state in the provision of social welfare services was very limited. On the other hand, a well-developed social welfare sector in civil society already existed as a result of the endeavours of churches, women's organisations and other organisations. However, Patel (2005:66-84) rightly points out that the development of the social welfare sector in South Africa took place along racial lines and was mainly focused on the white population group.

The establishment of the Department of Social Welfare introduced a new phase in the development of the South African social welfare sector, namely the development of a legislative framework to organise and regulate the social welfare sector. This process started seriously after the inception of the Department of Social Welfare in 1937. Two pieces of legislation became foundational in the course of time, namely the National Welfare Act (Act 100 of 1978) and the Fund-raising Act (Act 107 of 1978). The former Act aimed to make provision for the establishment and composition of a South African Welfare Council, regional welfare councils and certain committees, as well as to provide for the development of welfare programmes and the registration of welfare organisations (Republic of South Africa, 1978a:2). The aim of the latter Act was, amongst other things, to control fundraising in public (Republic of South Africa, 1978b:3).

Both acts required that social service organisations had to be registered according to a set of registration requirements (Republic of South Africa, 1978a:5, 1978b:7). The implementation of 
these acts consequently brought faith communities to the point where they had to take policy decisions on the position of their social service programmes. Many churches and other faith communities as a result decided to register their social services as welfare organisations and fundraising bodies.

Patel points out that, apart from the formally registered welfare organisations that worked in partnership with the apartheid government and received subsidies, many organisations also operated that did not register. She refers to them as the "informal sector" - "progressive development organisations" that had their origins in the trade union and liberation movements and formed part of the struggle against the apartheid government (Patel, 1992:53-69; 2005:82). This group of organisations did not receive subsidies from the government and were not organisationally as well developed as the organisations in the formal sector.

It was therefore necessary in the post-apartheid era to change existing legislation to accommodate the above-mentioned informal sector. The Non-profit Organisations Act (Act 71 of 1997) had to perform this function. The aim of the Act was to create an enabling environment in which non-profit organisations could flourish. It also had to establish an administrative and regulating framework in which organisations not for gain could manage their affairs (Republic of South Africa, 1997:2).

However, the Non-profit Organisations Act has not succeeded in being an instrument through which all social service and development organisations could register. This is not only because organisations are given a choice to register or not, but also because the act defines organisations only in terms of the form of their legal entities, namely associations, companies or trusts. As a result it is especially difficult for organisations from the faith-based sector to fit in, because of their own unique structures and organisational models. Indeed, if it is taken into consideration that a large number of social service organisations originated from the religious sector, Swilling and Russell's observation that a wide range of social formations in South Africa that came into being over the years can be forced into the category of "non-profit organisations" only with difficulty and without recognising their unique nature is relevant here (Swilling \& Russell, 2002:3).

The dawn of the new democratic dispensation in South Africa also heralded a new beginning for the social welfare and development sector in South Africa. According to the White Paper for Social Welfare (1997), social welfare policy in the post-apartheid dispensation rests on the partnership between the state and civil society. An important aim of the policy is therefore to promote and strengthen this partnership, which in the White Paper's identification of actors explicitly also involves organisations from the religious sector (Ministry for Welfare and Population Development, 1997:8). It follows that FBOs and the religious sector generally are thus recognised as a natural part of civil society and the partnership with the state in the new policy dispensation. In the establishment of such partnerships, however, another significant critical principle that has to be taken in consideration is the right of cultural, religious and language groups to establish, maintain and organise societies and other institutions as enshrined in Section 31 of the Constitution of South Africa (Republic of South Africa, 1996).

\section{Application of Sider and Unruh's typology}

This article supports the argument that in order for the religious sector to make a meaningful contribution to social welfare - and by implication social development - in post-apartheid South African society, a concerted attempt should be made to develop appropriate policies within which FBOs will be able to operate. The criterion of "appropriateness" is specifically 
used to indicate that such policies should provide space for FBOs to participate in the social upliftment and development of the country without jeopardising their unique identity and ethos. In this regard the argument by Sider and Unruh makes a lot of sense: "If public policy is to encourage the civic potential of the faith community, it must also accommodate the commitment to spiritual nurture that flows from the same source" (Unruh \& Sider, 2005:259).

So far some of the issues in the emerging debate on the role and contribution of the FBO sector in South Africa have been explained in this article. The typology of Sider and Unruh can contribute to this ongoing debate in a number of ways.

Firstly, the identification of different types of FBOs based on their religious connections opens the perspective that no generic or typical definition of an FBO needs to be developed. It has already been argued that one of the complicating factors in the conceptualisation of FBOs is precisely the understanding of the concept of "faith" as well as the unique languages that different faiths use. Different religions or faith groups, for example, have their own unique concepts to refer to the way in which their followers assemble to exercise their faith: the synagogues of the Jews, the mosques of the Muslims and the churches of the Christians. Some of the concepts can even have further multiple meanings, such as the word "church", which has different meanings for Christians, as Smit (2002:246), for instance, points out in a recent contribution.

Furthermore, every religion or faith community also has its own view of how to be involved in society and the social needs of individuals and communities. Some faith communities may prefer organised and formally structured programmes with employed staff, while others may prefer a more spontaneous involvement with the needs of people and communities. It also happens that some people interpret the term FBO in a very broad sense and include all organisations with some or other connection to religion, whereas others use the term in a very narrow sense, excluding all but those organisations that are religious in a narrow sense. The classification of types of organisations - faith-permeated, faith-centred, faith-affiliated, faithbackground and faith-secular - on the basis of the religious characteristics of the organisation and its programmes as well as the proximity of its connection with a particular faith community or religion is a creative contribution to the development of a generic language to describe FBOs.

The work of Sider and Unruh clearly shows that the term FBOs is an inclusive concept that can refer to actions or programmes initiated by faith groups, based on the convictions and values of that specific faith group that motivate them to become involved in society and address the needs of people and communities. These actions, in turn, can take on different forms. They can involve individuals or small groups of people who reach out informally, or they can be organised programmes aimed at a whole community or even a country or a region. Such organisations can be positioned further from or nearer to the faith community that established it. In the South African social welfare and development sector there are probably many such examples, for instance, BADISA (the social services organisation of the Dutch Reformed and Uniting Reformed Churches in the Western and Southern Cape), Hope Africa (the social development programme of the Anglican Church in Southern Africa) and the Salvation Army. Although these organisations see themselves as part of the church, they are linked to the church in different ways and the connection is reflected in different ways in their organisational structures (BADISA, 2003; Hope Africa website; Salvation Army, 2001). But there are also instances where faith groups take the lead in meeting the social welfare and development needs 
of their communities without establishing organisations. This is often the case in other African countries, where the social welfare sector is not always as well developed.

Secondly, the way in which Sider and Unruh use the religious content of organisational aspects as indicators to conceptualise FBOs can certainly be a valuable contribution to the South African debate on the conceptualisation of FBOs. They identify the tangibly expressive ways that religion may be present in organisations through its expression in observable and explicit phenomena such as language, symbols, policies and activities. These expressions of faith usually manifest in organisational documents such as the mission statements of organisations (FBOs), other internal policies, the composition of its governing bodies and the selection criteria for staff (Sider \& Unruh, 2004:117). This approach can be valuable in the current debate on the transformation of the South African social welfare sector. Issues such as transparency, democracy, accountability and the accessibility of social welfare services of FBOs form a critical part of the discourse (Department of Social Development, 2004). These issues pose a challenge to FBOs with regard to their internal policies such as the composition of their management boards, the selection of staff and their programme activities. The critical question in this regard seems to be how FBOs can remain faithful to their unique identity and ethos as expressed in their mission statements and internal policy documents, but also be part of the transformational agenda of the social welfare sector. At the same time the challenge for the state is how to acknowledge the uniqueness of FBOs in its policies.

An example can be the already mentioned: the Non-profit Organisations Act. In the discussion above the point was made that this piece of legislation categorises organisations in terms of existing legal categories. A starting-point in the discourse on how to deal with FBOs in social welfare policies could be to amend the NPO Act to provide for FBOs as a special type of NPO. In the process of establishing criteria for such types of organisations, the typology of Sider and Unruh can be very useful.

A third contribution of Sider and Unruh's typology to the South African discussion on the FBO sector is its focus on the religious aspects of social welfare programmes as a distinctive characteristic of FBOs. From the second half of the twentieth century the programmes of certain FBOs in the formal social welfare sector in South Africa started to lean towards religious neutrality. This tendency was the result of various factors. The dependence of FBOs in the formal social welfare sector on state subsidies that developed over the years is certainly a contributing factor. In the apartheid era social welfare programmes serving the white population group were given preferential treatment, as Patel shows. In 1976 state expenditure for social welfare for the white population group amounted to $56 \%$ of the total expenditure in comparison to $28 \%$ for black people and $16 \%$ for coloureds and Indians (Patel, 2005:71). This consequently led to a situation where it became attractive for FBOs rendering social welfare services to the white population group to receive substantial state subsidies. Another contributing factor was the close relationship that developed between those churches predominantly serving the white Afrikaans-speaking community and previous government, and the role that they (the Afrikaans-speaking churches) played in the development of social welfare policies, including the policy on subsidies from government. This led to a point where the line between faith-based and government policy became practically invisible.

A similar trend can be noted in the new democratic dispensation in South Africa. Dependence on state subsidy has brought FBOs to the point where they are confronted with the choice whether to accept the religiously neutral social welfare agenda of the state or to take the risk of a decrease in income. In order to maintain their position in the social welfare sector and the 
level of their service delivery, FBOs are therefore left with no other choice but to write their programmes according to the priorities of the state with the aim of getting the maximum state subsidy, rather than on the basis of the religious characteristics of the organisation. Khan correctly observes that in such circumstances "challenging government policy does not come into consideration" (Khan, 2007:24).

Finally, another factor that influenced the inclination of FBOs in the formal social welfare system in South Africa towards adopting neutral programmes is the professionalisation of Social Work, which started since the middle of the twentieth century. In many FBOs social workers play a key role in their programmes and it happens that choices for or against programmes are taken on the basis of social scientific and professional considerations rather than religious convictions. In this regard the comment of Kruger and Williams is relevant. These authors warn that "(s)ocial workers' tendency to ignore the relevance of spirituality in the lives of people might cause them to overlook a vital source of strength, growth and therefore empowerment" (Kruger \& Williams, 2003:307). In the current debate in the South African context on how the partnership between the state and the religious sector should develop, the challenge for FBOs is to ensure that there will still be space for religious aspects in their programmes.

A decisive point in the debate on the conceptualisation of FBOs that does not figure in Sider and Unruh's typology is the role of faith as a motivational factor for volunteers to become involved in social welfare. A number of studies on this aspect can be found in the literature, for example, Wuthnow (1991) and Unruh and Sider (2005), who did their research in the USA. However, similar research in the South African context is not available.

\section{CONCLUSION}

This article attempted to show why a more nuanced use of the term FBO is necessary in South Africa, as in other parts of the world. Although politicians and policy-makers in South Africa are of the opinion that faith communities and FBOs can make a noticeable contribution towards meeting the country's current social welfare and development challenges, it has also become apparent that not enough recognition is given to the peculiar identity of the religious sector. In the discussion it was argued that within a larger discourse on the development of a new, equal and non-racial social welfare and development sector for South Africa, a debate on the role and contribution of FBOs towards achieving this end should pay more concerted attention to the question of how the unique identity of FBOs can be accommodated.

It was furthermore pointed out in the discussion that authors world-wide have come to the conclusion that it is not so straightforward to determine a single, commonly accepted definition for FBOs. As a result these scholars rather propose a typology or classification consisting of various components according to which organisations in the religious sector can be classified. This article has argued that the typology of Sider and Unruh provides a helpful framework to describe South Africa's own faith-based sector and that further research on its application can provide a valuable contribution in the further development of social welfare policy in the country.

Besides the importance of being able to define who or what FBOs are, these organisations also want to be acknowledged in terms of their own peculiar identity and given a distinctive space in the social welfare sphere. In accordance with this recognition it was indicated in the discussion that the current transformation of the social welfare sector in South Africa and the development of new policies for the sector in more than one respect presents faith groups and FBOs with a 
dilemma. On the one hand, FBOs want to be faithful to the faith-based nature and contents of their programmes. On the other hand, however, they are part of the social welfare and development sector. This implies that the way in which social welfare policies are implemented often makes it difficult for FBOs to retain their own identity. In this regard the emerging partnership between the religious sector and the South African state can be an interesting venture that can inform social welfare policy in future.

But the discussion on the definition of FBOs also compels faith groups and the governing bodies of FBOs themselves to look anew at their identities and the distinctive nature of their programmes. The recent appeals of leaders from government to the churches and other FBOs clearly illustrate an expectation that the religious sector could make a unique contribution in the struggle against HIV and AIDS and poverty in the country. However, what this unique contribution could be has not been adequately researched and described. The typology developed by Sider and Unruh could serve as a useful instrument for FBOs in the new-found challenge to evaluate themselves and especially the contents and impact of their programmes.

\section{REFERENCES}

BADISA. 2003. Constitution of BADISA. Bellville: BADISA.

BOTHA, L.L.N. 1957. Die maatskaplike sorg van die NG Kerk in Suid-Afrika (19281953). Paarl: Paarl Drukpers.

CAMERON, H. 2004. Typology of religious characteristics of social service and educational organizations and programmes - a European response. Nonprofit and Voluntary Sector Quarterly, 33(1):146-150.

CNAAN, R.A., WINEBURG, R.J. \& BODDIE, S.C. 1999. The newer deal: social work and religion in partnership. New York: Columbia University Press.

DE KLERK, J.J. (red) 1990. Die diens van barmhartigheid en die Nederduitse Gereformeerde Kerk. Kaapstad: NG Kerk Uitgewers.

DEPARTMENT OF SOCIAL DEVELOPMENT 2004. Policy on financial awards towards service providers. Pretoria: Department of Social Development.

DEPARTMENT OF SOCIAL DEVELOPMENT 2006. Integrated service delivery model. Pretoria: Department of Social Development.

FARNELL, R. 2001. Faith communities, regeneration and social exclusion: developing a research agenda. Community Development Journal, 36(4):263-272.

GARLAND, D.R. 1997. Church social work. Social Work and Christianity, 24(2):94-113.

HOPE AFRICA WEBSITE. Available: http://www.hopeafrica.org.za/.

JEAVONS, T.H. 2004. Religious and faith-based organizations: do we know one when we see one? Nonprofit and Voluntary Sector Quarterly, 33(1):140-145.

KHAN, C. 2007. Faith, funding and the poor. Mail and Guardian, October 12-18.

KOEGELENBERG, R.A. 2001. Social development partnerships between religious communities and the state: perspectives from the National Religious Association for Social Development (NRASD). Journal of Theology for Southern Africa, 110:97-109. 
138

KOEGELENBERG, R.A. 2007. A creative church-state development partnership. In: SYMINGTON, J. (ed), South African Christian Handbook 2007-2008. Wellington: Tydskriftemaatskappy van die NG Kerk.

KRUGER, S.P. \& WILLIAMS, R.C. 2003. Exploring the role of spirituality in the lives of poor black women. Social Work/Maatskaplike Werk, 39(4):299-308.

LINDEQUE, R.C. 1982. Die maatskaplike werk van die Nederduitse Gereformeerde Kerk. Pretoria: University of Pretoria. (Unpublished doctoral thesis)

MIDGLEY, J. \& SANZENBACH, P. 1989. Social work, religion and the global challenge of fundamentalism. International Social Work, 32:273-287.

MINISTRY FOR WELFARE AND POPULATION DEVELOPMENT 1997. White Paper for Social Welfare. Government Gazette 1108 of 1997. Pretoria. Government Printers.

MUPEDZISWA, R. 1996. Social work and Christianity: complementarity or conflict? Social Work/Maatskaplike Werk, 32(4):378-386.

NETTING, F.E. 1984. Church-related agencies and social welfare. Social Service Review, 58(3):404-420.

NETTING, F.E. 2004. Commentary on typology of religious characteristics of social service and educational organizations and programmes. Nonprofit and Voluntary Sector Quarterly, 33(1):135-139.

NETTING, F.E., THIBAULT, J.M. \& ELLOR, J.W. 1990. Integrating content on organized religion into macropractice courses. Journal of Social Work Education, 26(1):15-24.

NIEUWOUDT, M.M. 1990. Praktiese implementering in die vaderlandse kerkgeskiedenis. In: DE KLERK, J.J. (red), Die diens van barmhartigheid en die Nederduitse Gereformeerde Kerk. Kaapstad: NG Kerk Uitgewers.

PATEL, L. 1992. Restructuring social welfare: options for South Africa. Braamfontein: Ravan Press.

PATEL, L. 2005. Social welfare and social development in South Africa. Cape Town: Oxford University Press.

REPUBLIC OF SOUTH AFRICA 1978a. The National Welfare Act. Act No. 100 of 1978, Government Gazette, Vol. 156 (No. 6094), Cape Town.

REPUBLIC OF SOUTH AFRICA 1978b. The Fund-raising Act. Act No. 107 of 1978, Government Gazette, Vol. 156 (No. 6099), Cape Town.

REPUBLIC OF SOUTH AFRICA 1996. The Constitution of the Republic of South Africa. Act 108 of 1996, Statutes of the Republic of South Africa Constitutional Law, Pretoria.

REPUBLIC OF SOUTH AFRICA 1997. The Non-profit Organisations Act. Act 71 of 1997, Government Gazette, 3, December 1997, No. 18487, Pretoria.

REPUBLIC OF SOUTH AFRICA 2007. Broad framework for HIV \& AIDS and STI strategic plan for South Africa, 2007-2011. Pretoria: Department of Health.

SALVATION ARMY 2001. The Salvation Army (Southern African Territory) constitution. Johannesburg: Salvation Army. 
SIDER, R.J. \& UNRUH, H.R. 2004. Typology of religious characteristics of social services and educational organizations and programs. Nonprofit and Voluntary Sector Quarterly, 33(1):109-134.

SMIT, D.J. 2002. Deel van "Kerk"deur die eeue - die werklike kerk op soek na die ware kerk. In: BURGER, C. \& NELL, I. (red). Draers van die waarheid: Nuwe Testamentiese visies vir die gemeente. Stellenbosch: Buvton.

SMITH, G. 2002. Religion and the rise of social capitalism: The faith communities in community development and urban regeneration in England. Community Development Journal, 37(2):167-177.

SWART, I. 2008. Meeting the rising expectations? On local churches as organisations of social welfare in South Africa. Paper presented at the Second Working Conference of the South African-Swedish Research Links Programme Project, "Welfare and Religion in a Global Perspective: Theoretical and Methodological Exchange Across the North-South Divide", Paarl, 12-14 March 2008.

SWILLING, M. \& RUSSELL, B. 2002. The size and scope of the non-profit sector in South-Africa. Johannesburg: Graduate School of Public and Development Management, University of the Witwatersrand and Centre for Civil Society, University of KwaZulu-Natal.

UNRUH, H.R. 2004. Religious elements of church-based social service programs: Types, variables and integrative strategies. Review of Religious Research, 459(4):313-335.

UNRUH, H.R. \& SIDER, R.J. 2005. Saving souls, serving society: understanding the faith factor in church-based social ministry. New York: Oxford University Press.

WUTHNOW, R. 1991. Acts of compassion: caring for others and helping ourselves. Princeton: Princeton University Press.

YEUNG, A.B. 2003. The re-emergence of the church in the Finnish public life? Christian social work as an indicator of the public status of the church. Journal of Contemporary Religion, 18(2):197-221.

Rev Willie van der Merwe, Secretary: Service and Witness, General Synod, Dutch Reformed Church, Hatfield, South Africa.

Prof Ignatius Swart, Executive Director: Academic and Research, Huguenot College, Wellington, South Africa.

Prof Jurgens Hendriks, Department of Practical Theology and Missiology, Stellenbosch University, Stellenbosch, South Africa. 